\title{
Manifestation of Chinese and American Values in The Wedding Banquet
}

\author{
Jiefei $\mathrm{Yu}$ \\ International College, Guangdong University of Foreign Studies, Guangzhou, China
}

\begin{abstract}
This paper mainly focuses on various cultural values and conflicts represented in the film The Wedding Banquet. In contrast with the civil marriage ceremony of American style performed in a Registry Office, the Chinese wedding is much more luxurious, filled with lots of over-elaborated formalities that are necessary in Chinese culture. The ceremony itself is considered more important than the notarization. Taking the subject of sexual orientation as a metaphor for larger cultural issues, the film is examined as identity confusion and inevitably, the pursuit of identity reconstruction. Through Wei-Tung's psychological struggles between Chinese traditional values and his homosexual desires, the film explores the possibility of a re-considered perception of identity for an Asian diasporic gay. Given the historical baggage brings with them, the process of the construction of identity for the immigrant is continuously dynamic and ongoing. After the implicit negotiations between ethnicity, sexuality, and patriarchy, the film story moves to reconciliation. This suggests that in such an era of multiculturalism, people had better come to realize their individual identities of diversity and complexity.
\end{abstract}

Index Terms - cultural values, wedding banquet, homosexual, identity

\section{INTRODUCTION}

The film The Wedding Banquet was directed by Ang Lee in 1993 with the primary plot of interracial romance. The film The Wedding Banquet has been honored at film festivals and hailed around the world.The prizes won include the nomination for the best foreign film at the 1994 Academy Awards,the Golden Space Needle of the Seattle International Film Festival and the Golden Bear by the Berlin International Film Festival. ${ }^{[1]}$ It tells a story about a young Chinese immigrant -Wei-Tung's life in America.Simon and Wei-Tung are a gay couple living together in Manhattan.To still the doubts of Wei-Tung's parents,Simon suggests a marriage of convenience between Wei-Tung and Wei-wei,an immigrant in urgent need of a green card.Complications arise when the joyous parents arrive for the wedding and a huge cross-cultural banquet is arranged to celebrate.However,being trickled by the guests in the wedding, Wei-wei seduces the drunken Wei-Tung and becomes pregnant.Simon is extremely disappointed when he finds it out,and his relationship with Wei-Tung begins to deteriorate.After several chaotic scenes of generational and cultural conflicts in the Gao's family,the film ends with a reconciliation:Wei-wei agrees to give birth to Wei-Tung's baby while Mr.and Mrs.Gao return to Taiwan with an acceptance of the gay couple's partnership.

\section{BODY}

\section{A. Different Attitudes toward Family in China and America}

"Historically the nuclear family served as the focal point of social organization and production in China and was firmly anchored in the Confucian philosophy of filial piety and the firm belief that the family is more important than the individual (Chao, 1983, p.121-125). The source of power in the family was firmly anchored in male authority patterns. Consequently the Chinese family is patriarchal and loyalty is important. Individuals are not simply members of groups but belong to groups. The traditional Chinese family assumed the nuclear form and consisted of the husband, wife, and their children. The father and his sons were the most important members of the Chinese family, as the male line of authority and inheritance could be traced back in time for progeny, and to future generations, to preserve and continue the male line of descent. Usually when the child comes to the age of marriage, the family elders would try to urge him to find out his proper partner. At the very beginning of the film, Mrs. Gao (Wei-Tung's mother) expresses her worry towards her son, by trying to set him up with Chinese-American women of similar background and interests, through a dating agency, called Singles Club. In the tape Mrs. Gao sends to Wei-Tung, she said, "you're not getting any younger yourself. When will you marry? You know, Pa came from mainland to Taiwan all by himself and you're his only precious son. So don't be such a snob! Last week we enrolled you into Taipei's best singles club and they'll send you a computer form for you to describe your ideal woman. All their girls have impeccable backgrounds. They are well-educated, well brought up, elegant and very attractive, like Mrs. Quian's daughter, the one you refused to marry. Please, son. Don't be so choosy." In this sense, marriage is considered a family affair rather than a matter of individual choice. Each family makes every effort to find the right woman to produce the mail heirs that were essential to the preservation of the family name and line of

\footnotetext{
${ }^{[1]}$ Please refer to essay titled "Xi yan - Awards" with its author unspecified. <https://www.imdb.com/title/tt0107156/awards?ref_=tt_awd>
} 
descent. The first time Wei-Tung's father sees Wei-wei, he says that, “Good. My investment paid off. She'll make lots of babies". Wei-Tung's life is considered as his father's own property and one reason why he satisfied with Wei-wei is that he thought she will produce many children for the Gao family. Wei-Tung's parents' views stand for traditional Chinese values in general, if not the Chinese culture itself.

Here we see that family is extremely important in Eastern culture, so no wonder why Wei-Tung's parents keep pressuring him to marry. In the film, Simon representing the west is the female in the relationship. Simon can cook, wears earrings and takes good care of Wei-Tung. Though Simon is a good partner and Wei-Tung's parents like him, he cannot produce any children. So, it is made quite apparent that Wei-Tung's parents' traditional ideas and ways of life will clash with the young people's new lifestyle. In Western/American society, identity is more about individuality. Family relationship is based on the autonomy, which means that each person should be treated as an individual first and only secondarily as a member of a group or the occupant of a position in a hierarchy (Wang, 2012). In individualistic culture, people tend to be less aware of others' feelings while self-reliance and independence are highly valued. Sometimes Chinese people would think that Americans do not take care of their elderly parents as well as Chinese do. But the Americans think that they do care for the elderly in a way that does not interfere with the autonomy and independence of the older person (Davis, 2001, p. 213). In the conversation about Simon's family between Wei-Tung's mother and Simon in the film, the characteristic of individualism revealed clearly in Simon. He knows his mother in Boston, while thinks that maybe his father is in Arizona. Talking about brothers and sisters, he says that: "Well, my father, who's quite old now, did have a son by a first marriage but I never met him. He died in the Vietnam War...I have two sisters; both of them live in San Francisco". Obviously, each person is seen as autonomous and separate in American culture. Thus, the different attitudes toward family would cause cultural-confrontation inevitably, especially in the exemplification of the huge wedding banquet.

\section{B. Cultural Connotation of the Wedding Feast}

The wedding culture is considered as a vital part of Chinese tradition. The holly marriage is practiced in honor of family value and respect to committed relationship. By holding the wedding banquet, the marriage status of the bride and groom is socially recognized by the people around them. Although young men and women enjoy much more freedom to choose their other half with the development of society, marriages are still chosen based upon the needs of reproduction and honor to some extent. ${ }^{[2]}$

In the film The Wedding Banquet, the tension is focused on homosexuality and generational/cultural differences. The old couple, Mr.and Mrs.Gao, come from Taiwan all for their son's wedding. They take 3000 dollars as gifts from their relatives and give many other special gifts to their future daughter-in-law for taking care of their son, such as natural pearls from Japan, red coral pin from Malaysia, gold bracelet from Old Chang and Mrs.Gao's priceless wedding Chi-Pao gown from mainland, all of which represent fertility and prosperity in Chinese culture. Despite Wei-Tung and Wei-wei's efforts to have a small non-religious marriage ceremony performed in a Registry Office, Wei-Tung's parents are able to plan an excessive wedding banquet with the help of a man who once was a subordinate of Wei-Tung's father in the military. Reluctantly, the newlyweds accept to hold a grand Chinese wedding feast finally for like Mrs.Gao's opinion, marriage happens only once in a lifetime and if there is no formal wedding banquet, what can they tell to their relatives? In her mind, marriage is a matter for others, rather than for young people themselves. So when they meet their old servant, old Chen, in the restaurant, the old couple accept old Chen's suggestion to hold a traditional Chinese wedding ceremony happily:

Old Chen: Young master, when did you marry? I have no gift for you. I must make it up to you.

Wei-tung: That won't be necessary.We just got married today at City Hall. Pa and Ma came for the wedding.

Old Chen: You got married at City Hall?

Wei-tung: That's right. This is our wedding dinner and we ran into you.

Old Chen: Young master, I know I'm out of line but the Commander is very well-known and respected. How could you have been so inconsiderate? I'm only a servant, but even when my third son was married I had a banquet for 200 guests. Allow me, Commander... Hey, I've got an idea! Although you kids want to be modem, what is a wedding without a banquet? So if you don't mind that my place is a bit small and the food not so great, it would please me if I could offer it to the young master for his wedding banquet. We have a party room and there is a hotel above. We can get a room for the newlyweds.

Wei-Tung: That would be too much trouble for you.

Old Chen: No trouble. Old Chen wants nothing better than to plan a banquet. All you have to do is show up. Look at the smile on the Commander's face. Young master, I'm not doing this for you. It's for the Commander. He's been going to other people's banquets for years. Now it's time for him to get back some of the gifts he gave. If you don't let him have this then you're an ungrateful son.

Wei-Tung: Won't this be too much trouble?

Old Chen: Then it's decided. Commander, leave everything to me. It'll be a great banquet! You won't lose face in America!

\footnotetext{
${ }^{[2]}$ For more information about Chinese wedding culture, please refer to essay titled "Complete Guide to Chinese Wedding" with its author unspecified. <http://www.chinabridal.com/etiquette/guide.htm>
} 
No words are more satisfying than these for the old couple at this moment and they get to prepare for the big day joyfully.

The next morning, Wei-Tung kneels to his parents as soon as gets up. This is a ritual for thanking his parents' upbringing. While for the bride, the procedures involved are much more complicated---"hair dressing" ritual is the first one in the morning. A "good luck woman", someone who is blessed with a good marriage, healthy husband and children and living parents, will come to help combing the bride's hair. In the wedding banquet, it is Sister Mao comes to help Wei-wei for her hair-dressing. Traditionally, the groom's family also conduct "capping" ritual for the groom at their home. In Chinese culture, these rituals signify that the new couple are reaching adulthood and they are supposed to take on adult responsibilities. When they are ready for these, the bride and bridegroom would come to offer tea for their parents, which is also ceremonial. At this official ritual, parents give their words of blessing and gifts to the newlyweds. The "good luck woman" would say some auspicious phrases to the new couple. In the film, Wei-Tung and Wei-wei kneel to Wei-Tung's parents three times, and each gets a red envelop of money back. After this, both of them are asked to kneel again for lotus soup, for it is said that, "Have some lotus soup, a son will come quickly". A young boy, named Stone, is invited to jump on the bridal bed to bring fertility to the newlyweds. Marriage is representative of the passing down, of delivering offspring, so that the family name could be continued. Thus it is the end of the ritual and the wedding proceeds to the banquet venue.

Traditional Chinese wedding was very strict about the wedding dresses. However, there are some variations in the case nowadays. Usually, there will be three different dresses for the bride at the wedding day. She would start with white dress with veil in western style. Then at the tea ceremony and the banquet, she would change into traditional Chinese bridal dress --- red Cheongsam. The color red is thought to be auspicious, a strong color that can drive away evil spirits. Finally, before the bride leaves the banquet, she would change into a cocktail dress to see the guests off at the door. In this sense, this last dress is also known as "going away" dress. In the film, Wei-wei did change her dress many times in this big day.

The food served in the wedding banquet in the film also very abundant. Certain typical Chinese wedding food are served, which include fish, roast suckling pig, chicken cooked with red oil, lobster and desert bun with lotus seeds stuffed inside. The pronunciation of fish, $y u$, sounds like the word for riches or abundance, meaning the newlyweds will be blessed with large amounts of wealth. Roast suckling pig is served whole, symbolizing the purity of the bride. Chicken also means phoenix, cooked in red oil with the wish for a wealthy life ahead for the new couple. Lobster literally means "dragon shrimp" in Chinese. At wedding banquet, having lobster and chicken together means that the dragon and the phoenix are harmonious together, and the Yin and Yang elements in this family are well balanced. Alcoholic drinks are necessities at a wedding banquet, and the bride and groom often toast to each table of the banquet. They will usually be teased and join in games at the banquet. In the film, Wei-Tung and Wei-wei are compelled to toast all guests, as who shout that "Just can't toast an entire table and just take a short sip. You must toast a full glass to each of us. We all come from far away". The carnivalesque performances designed become an exotic tour of the taste for non-Chinese audience.

\section{Who Is the "Other": Orient or Occident?}

If it is as true as Foucault (2010) declares that "power is everywhere; not because it embraces everything, but because it comes from everywhere" (p.93), the power relations in ethnicity construction in the American cultural supermarket then is rather complex and subtle because there various forms of cultures clank and clash in everyday huddle and hustle. In such a cultural supermarket, ethnicity can be demonstrated in peaceful multiculturalism coexistence, in discrimination or in violent inter-ethnic confrontation (Conrad, 2002). In the "Melting Pot" style, ethnicity must be discarded and rejected while mainstream culture must be adopted and acquired; and when it comes to the modem multicultural era, the cultural difference is respected or even elaborated, and cultural choices become more diverse and personal-related.

In the film, though many American guests come to attend the wedding banquet as friends, the Chinese still cannot actually enjoy the consent or identification from them. Asians has been thought to be racially undesirable, a race that could never be successfully assimilated into the mainstream of American life for more than a century. All the Americans rely on the Western knowledge for their judgment on China. So even American culture establishes a cultural supermarket and encourages multicultural coexistence there, it can never avoid the double-edged nature of cultural norms, which authorizes the cultural insider and marginalizes those newcomers from outside.

Basically, according to Elaine Kim (1982), there are two kinds of stereotypes of Asians in American popular culture: the "bad" Asians-sinister villains and brute hordes who cannot be controlled and must therefore be destroyed-and the "good" Asians-helpless heathens, loyal sidekicks, docile servants, and seductive female sex partners who pose no apparent threat. ${ }^{[3]}$ In both cases, the images of the Asians portrayed by Anglo-American mainly serves as a foil for the Anglo: when the Asian is cruel and duplicitous, the Anglo is presented indirectly as righteous and humane; when the Asian is a agreeable and obedient inferior, the Anglo is projected as kind and important. The comical, cowardly servant placates a strong and intelligent white master; the helpless heathen is saved by a benevolent white savior; the clever Chinese detective solves mysteries for the benefit of his ethical white clients and colleagues. What both the "bad" and the "good" Asians have in common is that they define the Anglo as physically, spiritually and morally superior.

\footnotetext{
${ }^{[3]}$ Refer to Elaine H. Kim, (1982). Images of Asians in Anglo-American Literature. Asian American Literature: An Introduction to the Writings and Their Social Context. Philadelphia: Temple University Press. pp.3-22.
} 
This marginalization of ethnicity, as Shohat (1996) argues, "reflects the imaginary of the dominant group which envisions itself as the 'universal' or the 'essential' American nation, and thus 'beyond' or 'above' ethnicity"(p. 215).To separate the "Center" from the ethnic "other" and to universalize the American "Center", the domination culture must work out an ontological and epistemological distinction between "the Orient" and (most of the time) "the Occident" (Said, 1977). In multiculturalism, where cultural diversity is encouraged and cultural identification is respected, cultural distinction is invisibly promoted and intensified. Even though multiculturalism advocates the peaceful coexistence of dominant and ethnic culture, it can never eliminate the logic of binary oppositions and the marginalization of ethnicity. Once the ethnic form of other cultures becomes a threat or challenge to the "Center", it is misinterpreted or suppressed by the host culture, or reinvented to its own taste. The American people's "insatiable appetite" for lurid stories about Chinese made almost every area of Chinese life a popular topic in American life and culture for generations (McClellan, 1971, p.13). Chinatown, which has been considered as a den of vice peopled by opium addicts, tong assassins, and slave girls by the Americans for a long time. This stereotype about Chinatown strengthened already widespread misconceptions about Chinese in America and so caused many misunderstandings. According to the popularly accepted mythology, no matter how "American" the Asian might seem, he was ultimately an unassimilable alien. That is because race stereotypes essentialize or ignore specifically human qualities and thus there are no "favorable" stereotypes. "Good" Chinese are simply friendly to whites, and "bad" Chinese are hostile. Both are grotesque parodies, portrayals in a vacuum, and both serve to emphasize the inherent superiority of the white race. Barbaric Asian hordes can be seen as masses of helpless heathens; all are faceless, lacking in individual identities, and both are defined by the white hero that subdues or saves them. The popular image of the Asian woman is that they are warmly sensual, imbued with an innate understanding of how to please her man and how to serve him. In this sense, the Chinese are treated as the "Other" to the Americans. The "Other" helps the Americans to know who they are because the "other" provides an example of what they are not. Kian Woon Kwok (1996) describes the importance of the "Other" to the construction of social identities:

"Identity is a relational concept; it implies a relationship between one group and an Other or Others, whether real or imagined, whether clearly specified or not. Thus, part of the process of identifying "us"is to make the Other out to be different. In some instances, the Other is clearly specified and the relation is that of "us" vs. "them". Thus "us" is identified by how "they" perceive "us" as "their Other," and a more conscious position is taken to counter their perception of us if it is negative and to confirm it if it is positive. In either case, when this is done, the group consciously or unconsciously builds its self-image through the perception of others".(p.25)

The construction and adoption of a racial and ethnic social identity represent a constant negotiation between self and other identification, which indicates the implications attached to possible identities and bounds. Alejandro Portes and Dag Macleod (2010) describe the process as a symbolic interaction between ethnic minorities and the host society that involves a dizzying loop: "what they think your ethnicity is influences what you think your ethnicity is, to say nothing of what they think you think your ethnicity is"(p.14). The orientalist ideology explains this in a special way that the western "Center" to conquer and control the oriental "Other". Orientalism, as Said (1977) elaborates, is

"Ultimately a political vision of reality whose structure promoted the difference between the familiar (Europe, the west, 'Us')and the strange (the orient, the east, 'them') ... when one uses categories like Oriental and Western as both the starting and the end points of analysis, research, public policy...the result is usually to polarize the distinction---the Oriental becomes more Oriental, the Westerner more Western---and limit the human encounter between different cultures, traditions, and societies" (p.22).

Orientalism, emerging out of an epistemological need to differentiate "Us" from "Them", has become a special form of ethnocentrism and racism. Accordingly, how to understand the different rituals in Chinese wedding banquet determines the American construction of the Chinese race in its own discourse. In the operation of power discourse-Chinese culture as the powerless "Other" cannot truly and truthfully define and identify itself, hence becoming a floating signifier waiting for the Western "Center" to define and redefine.

In the film, the process of cultural confrontation makes Wei-Tung realize the dubility of his own cultural identity. For all Chinese, especially for the old generations in the film, all the Americans are their cultural "other" because they cannot understand the traditional rituals of wedding. And moreover, when finally does Wei-Tung confess his secret, his mother, Mrs.Gao considered that homosexuality as a kind of "sickness" and it is Simon led his son astray. "Simon led you astray?... Why? You did have girlfriends in college! You are quite normal at that time." Different apprehensions of each other culture lead to misunderstandings. Every culture in the formation of its civilization is not impregnable to the "Center-Other" binary logic and will develop on the basis of its opposition with "the big Other" and "an unshakable belief in a consistent Other, an Other without gaps, an "Other of the Other"(Wu,1991,p.179). This "Center-Other" cultural relations become more complicated in the trend of globalization. Fanon(2008) once commented that "in the soul of those colonized, an inferiority complex has been created by the death and burial of its local cultural identity" (p.18). To the immigrants in The Wedding Banquet, they may still believe they are the "Center" and the Americans the "Other", but the reality in the cultural supermarket will surely shake and destroy their ethnocentric illusion. All of them must give up some of their rights, values, and traditions for gaining what they want. Looking first at Mr.Gao, at the last scene of the movie, he puts his hands up as in surrender to the American security guard in the airport. This act means the surrendering of his Eastern identity so as to be adapted into Western culture and get his wishes realized. For Wei-wei, though at last she 
decides to keep the baby, she says that she sacrifices too much for the green card: "Maybe there are more important things in life than hiding in America. We are so selfish. For our own interests, we planned this bogus marriage. We let Simon down your parents, too. If we continued, we'd let the kid down, too".

So it is the distinction or positioning of "Center" and "Other" determined by the power of discourse. It is always two-way directional, although the host culture often has the privilege. As Richard (1999) points out, "the representation of white people serves the interests of white people...it allies whiteness with power, intelligence and enterprise, with will and control (of self and others) (Beverley,1999, p.135). The discursive and ethnocentric representation in fact is not a western monopoly but rather a universal phenomenon in every culture. So neither Orient nor Occident is the "Center" or the "Other".

\section{Negotiation of an Asian Diaspora Queer Identity}

Structured as a domestic tragicomedy, The Wedding Banquet also explores the protagonists' struggle to recognize their gay identity as individuals. As Smith (1997) defines individual identity as:" it is not of a common denominator of patterns of life and activity, much less some average, but rather of subjective feelings and valuations of any population which possess common experiences and one or more shared cultural characteristics (usually customs, language or religion)"(p.171-91). Quite contrary to the collective identity, the "individual identity" shifts the focus to the subjective world and emphasizes the individual choice of identification. But when confronted by the shaping power of the dominant culture, he is not always passive and helpless but is instead more or less privileged with the right to choose and identify with, especially in the case of immigrants who are dislocated from their born culture. In other words, individual identity is the sense of "self", "the essential core of who we are as individuals" and "the conscious experience of the self inside" (Kaufman, 1996, p.68). And this individual identity is, to a large extent, subject to the construction of subjectivity which refers to "the conscious and unconscious thoughts and emotions which constitute our sense of 'who we are' and positions within culture"(Woodward,1997,p.39). In this light, a certain complex relationship exists in the triangle between identity, subjectivity and culture. Identity is constructed in the formation of subjectivity, and the construction of subjectivity cannot escape the shadow of culture, which not only inflicts the necessary shaping for subjectivity but at the same time provides a certain level of freedom under its normative regulations. In one word, "identity is formed at the unstable point where the 'unspeakable' stories of subjectivity meet the narratives of history, of a culture"(Hall,2000,p.135).

However, when it comes to the immigrants, identity problem, the tranquility in the Identity-Subjectivity-Culture triangle is disturbed as the composition of power relations within is correspondingly restructured. When Chinese immigrants are still at home, they are subjected to Chinese culture and that dominants every corner of their minds. Under such a condition, their individual identity overlaps with their collective identity and they never have cultural identity problems. However, after they arrived in America as immigrants and are dislocated and exiled from the born culture, the discordance between two identities appears, and the individual identity is highlighted in the new environment. The host culture encourages them to take a new life, but the past cultural memories still linger in their inner mind. Thus, the two cultures compete each other for the control of their subjectivity and the subject becomes "the site of a discursive battle for the meaning of their identity," and "their interpellation as subjects within any single discourse can never be final"(Easthope,2004,p.68-9).

For Wei-Tung, the central protagonist of the film The Wedding Banquet, these elements are in conflict. As both diaspora and gay, Wei-Tung becomes "an anomaly", consequently there is no fixed identity for him. His identity-orientation process is engaged in negotiation between his ethnicity, sexuality, and his father's patriarchy. This dilemma shows that the process for an immigrant to construct his new identity is entangled with his past memory, which will continually inflects the present, controlling its future trajectory. Wei-Tung is a Chinese American coming from a wealthy but traditional Chinese family. He is the cherished, only son from a culture which takes only the males as permanent members of a family. Whatever decisions Wei-Tung make will reflect on his family, bringing shame or pride to his ancestors as well as descendants(McGoldrick,2004).

Wei-Tung lives with two identities. On the one hand, he successfully managed to be assimilated into the western culture. In America, Wei-Tung is a promising realtor. He drives Mercedes-Benz, reads World Trade and Fortune, works out at a fitness club regularly, and owns an expensive Manhattan brownstone in mixed neighborhood. He appears to revere his parents, carefully storing each item sent to him from them. He pretends to have the "normal" sexual orientation as what his parent expected, in order to protect them while he participates in a loving, stable homosexual relationship. All of these show that he has evolved into the trajectory of American identity at the beginning. On the other hand, no matter how much Wei-Tung loves and respects his parents and carefully keeps all of their tokens and gifts, he dares not to tell them his real sex orientation. However, by protecting his parents from this very knowledge, it is very difficult for Wei-Tung to reconcile himself to his own identity. According to Zastrow and Kirst-Ashman (1994), a “...gay person with a heterosexual facade is burdened with pretending to be someone he or she is not. Such pretense can violate individual dignity and freedom" (p.543).

As for individual identity, Rutherford (1990) once said, "each individual identity is the synthesis not only of existing relations but of the history of these relations" (p.19). At the crossroad between history and future, and trapped in such an identity dilemma, Wei-Tung has to make a choice of his individual identity and reconstruct his subjectivity in the clash of the two contradictory identities. As an immigrant in a new place, he certainly should make some sacrifice of his past life and adapts himself to the different cultural norms. So he picks up English language and American lifestyle, and toils day 
and night on the way to his American dream. He seems reached this goal until the unexpected coming of his parents and the holding of the huge wedding feast. As a Chinese, Wei-Tung has the responsibility to carry on his family line, just like what Anzaldu (1999) says, "I am a turtle, wherever I go I carry 'Home' on my back"(p.893). He stuck in a dilemma. It is impossible for him to go back to be a traditional obedient son and there is no home to return. The "home on his back" is just what he imagines, for that "migration is a one-way trip", and there is never a historical home to return to (Hall, 2000,p.134-135).

Obviously, we can sense the exilic temperament of the immigrant's identity imposes great pressure on Wei-Tung. Since many cultures have had, and unfortunately continue to have, an overwhelmingly homophobic view, it is not surprising that Wei-Tung keeps this sexual orientation as a secret, is afraid of his parents' reaction and the familial ramifications that his "coming out" would bring(Klein \&Michael,1998). For Wei-Tung, there is tremendous pressure to carry on the family line; therefore, by admitting to his parents that he is a homosexual, Wei-Tung carries the additional burden of letting down his ancestors and the future descendants that will never be. And though the huge wedding feast did bring him back to the memory of Chinese culture, the source of his past identity, it cannot provide a final and definite solution to his identity crisis in America, and can only leave him an imagined and metaphysical "home" to identify himself with. In either case, he would remain in a state of imagined identification. The awkward position is, as Said (1977) explains, "you cannot go back to some earlier and perhaps more stable condition of being at home; and, alas, you can never fully arrive, be at one with your new home or situation (p.39). For Wei-Tung, it is hard for him to be the good son while also being at peace with being homosexual. He suffers the fragmentation of identity and the confusion of role. No matter how obedient he shows to his parents, he can never return to his past and assume his past unitary and stable identity as a Chinese.

In order to better understand the difficult situation Wei-Tung is in, we need to examine why Chinese culture refuses to accept homosexuality. The core Chinese cultural value is collectivism which gives great emphasis to the survival of their lineage. Having a son to carry out their family name is critically important for most traditional Chinese. Consequently, Mr. and Mrs. Gao suffered a major meltdown when finding out that their only son is a gay. They expect much for him, and expect it rigidly. These expectations cause him interpersonal conflicts; hence "coming out" becomes Wei-Tung's most difficult developmental challenge (Zastrow and Kirst-Ashman,1994). Minton and MacDonald(1993) conceptualize "coming out" as a "life-spanning developmental process that eventually leads to personal acceptance of a positive gay self-image and a coherent personal identity" (Laird,p.304). Wei-Tung dares not to speak out the truth to his parents, for which he believed would prevent his self-actualization and personal growth. As he confessed to his mother that, "I was afraid you couldn't take it. It's been 20 years. I've been living a big lie. There has been so much pain and joy. I've wanted to share with you, but I couldn't. Sometimes I wanted to tell you everything but I couldn't burden you with what has been with me so long". This is a big strike to his mother and she thinks that it is Simon led Wei-Tung astray and set many examples that Wei-Tung did have many girlfriends when he was in college. For most Asian parents, "gay" is something exotic, there is simply no necessity to give a thought about it because it is only a problem for white people: it is a white disease. In this context, it is no wonder why Wei-Tung's mother cannot accept this fact that her son is homosexually oriented.

So living between two cultures and keeping certain distance from both, the immigrant suffer from the lack of belongings. Potentially, the exilic situation of immigrants' identities means the birth of an entirely new hybrid identity instead of the old collective ones, if the individual identity transcends traditional thinking and thinks beyond the framework of binary opposition. The new hybrid identity is not the simple overlapping of two collective identities, but as what Homi Bhabha (2004) describes: "an emergence that turns "return" into "reinscription" or "redescription"(p.227). In this sense, the exilic identity is not something between the two collective identities, but something outside of them or even something against them. With its ambivalence produced within the rules of recognition of dominating discourse, the hybrid identity resists against the grains of both cultures and their collective identities as it articulates the signs of culture difference (Bhabha, 2004,p. 153).

In this sense, it is "the exile of identity" that encumbrances the reconstruction of the Chinese immigrants subjectivity and make the immigrants suffer in the clashes between the two collective identities. The immigrant as only a temporary site of identity will eventually evolve towards either of the two collective identities, but it can never orbit in their trajectories for long. The only destination for him is exile or hybridity. If Wei-Tung confessed his gay relationship at the very beginning and adopted a kind of new thinking towards identity problems, he would have realized the potential hybridity in the meaning of exile and would have accordingly changed his way of communication with his parents, and if that had been the case, everything would have been quite different.

\section{CONCLUSION}

In the American cultural supermarket, the Chinese immigrants like Wei-Tung and Wei-wei are willing to embrace the freedom of choice and enjoy the diversity of culture and the fluidity of identity, and at the same time bring with them their native cultural segments from the periphery into the American core and greatly enrich American culture. In the film, the Chinese way of wedding banquet and the case of homosexuality induce the strong confrontation between Chinese and American cultures and their respective ethnic identities. As a subject of both cultures, Wei-Tung has at first meant to carefully balance himself in between, and this binary thinking of identity impedes the reconstruction of his immigrant 
subjectivity and makes him suffer in the clashes between two collective identities. Fragmented between the born and adopted cultures, the reconstruction of Wei-Tung and Wei-wei's consciousness cannot be complete and unified because their identities can only remain an unstable site of confrontation and communication in such a situation. The fragmentation of subjectivity determines that Wei-Tung and Wei-wei can only be Sino-American cultural hybridity; any partial orientation towards either culture will result in the crisis of cultural identities. While for the Americans, their "hybridity-phobia" and resistance to hybridity is the main barrier in their adopting new attitudes toward cultural identity problems, therefore to be a strong hindrance to a fair understanding to the Chinese culture. Finally through the temporary dislocation of the born culture and the momentary cultural projection into the ethnic Chinese culture, American culture will be able to succeed in its liberation from hybridity-phobia and learn to accept and appreciate the ethnic forms of culture alien to it. In this sense, diaspora culture is an everlasting, never-stopping process, and the relationship between the diaspora culture and the host culture is a negotiation. The aim for the long process of negotiation is not a world without difference, but a world without estrangement.

\section{REFERENCES}

[1] Alejandro Portes and Dag Macleod. (2010). What shall I call myself? Hispanic identity formation in the second generation. Ethnic and Racial Studies. Abingdon: Routledge Journals, Taylor \& Francis Ltd.

[2] Anzaldau, Gloria. (1999). Borderlands/La Frontera. Eds. Julie Rivkin and Mivhael Ryan. Literary Theory: An Anthology. London: Blackwell Publishers, 893-1017.

[3] Beverley,John. (1999). Subalernity \& Representation. London: Duke University Press.

[4] Bhabha,K.Homi.(2004).Within Third Space. Location of Culture. Ed. Homi Bhabha. London: Routledge.

[5] Chao,Paul. (1983). Chinese Kinship. London: Kegan Paul International.

[6] Conrad, Kottack, Phillip. (2002).Cultural Anthropology. New York: McGraw-Hill Higher Education.

[7] Davis, Linell. (2001). Doing Culture: Cross-cultural Communication in Action. Beijing: Foreign Language Teaching and Research Press.

[8] Easthope, Antony and McGrown Kate. (2004). A Critical and Cultural Theory Reader. Buckingham: Open University Press.

[9] Fanon,Frantze. (2008). Black Skin.White Masks.Charles Lamm Markmann(trans.).London: Pluto.

[10] Foucault,Michel. (2010). The Archaeology of Knowledge and the Discourse on Language.New York: Vintage Books.

[11] Hall,Stuart. (2000). Cultural Identity and Diaspora. Cultural Studies: Theory and Practice. Ed. Chris Barker. London: SAGE.

[12] Klein,Lisa C.\&Michael,Jody. (1998). Who am I?:Issues of Identity for an Asian Gay Male in American. The Advocate's Forum, SSA Publications,5(1). http://www.ssa.uchicago.edu/publications/advforum/v5n1/v5i1a1.html.

[13] Kian Woon Kwok. (1996). Historical Discontinuity and Cultural Dislocation: The (Non-)Problem of Social Memory in Singapore, paper presented at the conference on Trauma and Memory. Durham: University of New Hampshire.

[14] Laird,J.(1993).Lesbian and gay families. Ed.F.Walsh. Normal family processes. New York: The Guilford Press,282-328.

[15] McGoldrick, M. (2004). Ethnicity and the family life cycle. Eds. B.Carter,\&M.McGoldrick. The Changing Family Life Cycle: A Framework for Family Therapy. New York: Gardner Press.

[16] McClellan,Robert. (1971). The Heathen Chinese. Columbus: Ohio State University Press.

[17] Rutherford,Jonathan. (1990). A Place Called Home:Identity and the Culture Politics of Difference. Ed. Jonathan Rutherford. Identity:Community,Culture,Difference. London: Lawrence\&Wishart,12-38.

[18] Said, Edward. (1977). Orientalism. New York:Vintage.

[19] Shohat, Ella \& Stam, Robert. (1996).Unthinking Eurocentrism: Multiculturalism \& the Media. London: Roultedge.

[20] Smith, D. Anthony. (1997). Towards a Global Culture? Theory, Culture \& Society. London: Sage, 7:81-91.

[21] Woodward, Kathryn. (1997). Identity and Difference. London: Sage.

[22] Wang, Ying. (2012). Differences between Sino-American Cultural Values from Intercultural Communication Perspective. 2012 Second International Conference on Business Computing and Global Information.

[23] Wu, David Yen-ho. (1991). The Construction of Chinese and non-Chinese Identities. Dadalus 120.2:159-79.

[24] Zastrow, C., Kirst-Ashman, K. (1994). Understanding Human Behavior and the Social Environment. Chicago: Nelson-Hall

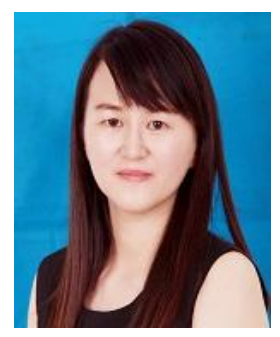

Jiefei Yu was born in Anqing, Anhui province in Oct., 1984 and was graduated from Guangdong University of Foreign Studies in Guangzhou, China in 2008. Her major field of study is English language and literature. She works in International College of Guangdong University of Foreign Studies since she was graduated. 